\title{
Bibliometric study of the Indian journal of economics
}

\author{
Nitesh V Chore \\ Librarian, Vinayak Vidnyan Mahavidyalaya, Nandgaon, Amravati, Maharashtra, India
}

*Corresponding Author: Nitesh V Chore

Email: niteshchore123@gmail.com

\begin{abstract}
This paper presents Bibliometric study of The Indian Journal of Economics during the period of 2012 to 2019.Researcher has to examined 229 articles has been published during the period of study. The paper examined year wise distribution of articles, subjectwise distribution of articles, in Authorship pattern 397 author was dected, 229 articles have received 3529 citations, Subject facet highest no of articles published i,e. 64 papers have published in commerce. Singh D V is the most prominent author he published 14 authors during the study. Such as Geographical distribution of publication New Delhi is the top total 27 articles published, highest length of articles is 64 pages during the span of study have been analyzed.
\end{abstract}

Keywords: Bibliometric study.

\section{Introduction}

This is an age of research and expedition in every field of knowledge. The consequent increase in the production of information is best reflected in the literature of every discipline. Due to the expeditious growth and burgeoning development, libraries engender various studies, which must be efficacious in nature. These studies resulted in discernment and application of suit-able quantitative measuring techniques known as Bibliometrics. Bibliometric studies project the pattern of literature growth, its use, correlate diverse branches of knowledge, build up template of collection, productivity and influence authors, etc.

Bibliometrics is a type of research method used in Library and information sciences. It is an emerging area of research in the Library and information science field. The term "Bibliometrics" was first coined by Pritchard 1969, and its usage and practice can be traced back to the second decade of this country. It is the statistical analysis of texts and information. It utilizes quantitative analysis and statistics to describe patterns of publication within a given field or body of literature. Bibliometrics is an emerging thrust area of research and has now become a well established part of information research and a quantitative approach to the description of documents. It has grown out of the realization that literature is growing and changing out of a rate with which no librarian or information worker equipped with traditional bibliographic skills and methods could keep abreast.

Bibliometrics is a set of methods used to study or measure texts and information (Wikipedia, 2011). A bibliometric analysis is employed by many researchers to study the literature in a given field. Such a study is often carried out by counting the references cited by a large number of researchers in their papers. The term Bibliometrics is derived from two distinct words, biblio and metrics. The word biblio is derived from the combination of the Latin and Greek word biblion, meaning "book" or "paper" while the word metrics indicates the science of meter, i.e., measurement and is also derived either from the Latin word metrics or the Greek word metrikons, both meaning "measurement". Therefore, bibliometrics connotes the science of measurement pertaining to books or documents. In a sense, information science is an extension of library science or an expansion of reference services. In other words, bibliometrics is a branch of science, which studies the behavior of information. Traditionally, it is associated with the quantitative measurement of documentary materials.

The Indian Journals of Economics is a reputed Quarterly journal published during 2010-2017 has been taken as source for the purpose of study. Citation appended in the articles in the source journal of The Indian Journals of Economics was collected for the study of bibliometrics.

\section{Review of Literature}

This article reviews a few studies conducted various scientist on Bibliometrics study.

Abdullah and Kaur (2002) explore the Malysain Journal of Library and Information Science for period of 1996 to2000.in his study he found average number of reference per articles 22.5 and length was 41.2 pages. Barkari and Willet (2008) covering the period 2001 to 2006 they found that number of publication was increase statically and significance changes in types of paper. Tiew (2000) found the $53 \%$ of articles contained journal self citations. Bhattacharya and Verma (2006) analysed growth pattern core journal and authors in the field of bibliometrics using data of LISA. Dhaman (2000) has done 10 years of Bibliometrics study in Ethenobotonay journal he found that institution wise, country wise, Authorship pattern, Reference cited and length of articles. Thanks kodi (2010) examined data of social scientist on social science subject. He analyzed authorship pattern, subject wise distribution of article, average no of reference per article, cited article in year wise

\section{Status of the source Journal}

The Indian Journals of Economics is published regularly since 1987, a leading refereed quarterly journal, is the official publication of Indian Institute of Finance. Each 
issue is of about 450 pages. The journal has an exalted board of editors including nobel laureates and other leading professionals from all over the world. FI is ranked at par with top international journals. The journal is Indexed / Abstracted in the Cabells Directory of Publishing Opportunities in Accounting, Economics and Finance 199798, International Bibliography of Social Sciences of the London School of Economics \& Political Sciences, Econ Lit, JEL on CD, e-JEL, the journal of Economic Literature, Pro Quest, Ulrich's Periodicals Directory, ISID Research Reference of Institute of Studies in Industrial Development, Gale Directory of Publications \& Broadcast Media, FI-ICP, Online Public Access Catalogue of Indian Institute of Management Ahmedabad (IIM-A), EDIRC, All India Index to Periodical Literature by Nexus Information Services Company (NISC), British Library for Development Studies at IDS, Information Bulletin on Management (IIM-A), Economic Journals on the Web, SOASEA (South Asia Economic Abstracts) of Information Research Group, Finance Wise, Social Science Information Gateway(SOSIG), Finance Step and others.

The primary aim of the journal is to promote research by disseminating the results of such research in finance, accounting, financial economics and related areas. The journal is intended to provide scholars a major forum for inter and intra disciplinary study of various aspects of finance. The journal is published in March, June, September and December four times a year. The Indian Journals of Economics rated 3rd worldwide amongst 79 finance institutions and also among 148 Institutions of finance, macro economics, labor \& general micro-economics and business datasets by Business and Economic Data links of American Statistical Association based on ratings for providing financial information $\&$ database.

\section{Objectives of the Study}

The study has been carried with the following objectives-

1. To verify the authorship pattern.

2. To find out the scientific productivity of journals.

3. To find out the growth in literature.

4. To find out dominant subject facets

5. To find out the quantitative research output.

\section{Scope of study}

The research journals are the vehicle for scientific and scholarly communication in the present study "The Indian Journal of Economics" is selected as a source of information considered the issues of the said journal during the period of 2012-2019.

\section{Methodology}

Bibliometric technique will be used analyzed the citation appended in research articles published in the Indian Journals of Economics. The database of the citation appended in the articles in source journal published during 2010-2017 will be developed and analyzed according to the objectives of the study. The following software will be used to developed database and analyses.MS-EXCEL, MS-word.

\section{Imperical Laws of Bibliometrics \\ Brad ford's law of scattering}

Brad ford's law describes the patterns of scatter of literature on a subject in various periodicals. This is based on his paper on 'scatter if paper on applied Geophysics and lubrication.

According to his, if scientific journal are arranged according to decreasing productivity of articles on a given subject, they can be divided into a nucleus of periodicals more particularly devoted to a subject and several other groups or zones containing the same number of articles as the nucleus when zones will be 1:n:n2

$\mathrm{F}(\mathrm{x})=\mathrm{a}+\mathrm{b} \log \mathrm{x}$

Where $F(x)$ is the cumulative no. of reference as contained in the first $\mathrm{x}$ most productive journal and $\mathrm{a}$ and $\mathrm{b}$ are constant

\section{Lotka's Law}

Lotka's law related to a study of the productivity of authors. He studied the productivity of authors of frequency of publication listed in the 'chemical abstracts' for the period 1907 to 1916.

He found that the productivity of scientists confirmed to inverse square law such that for every 100 authors contributing one articles, 25 will contribute 2 articles, 11 will contribute 3 articles and 6 will contributes 4 articles. Based on his study of chemistry and physics literature.

\section{Zipf's Law}

Zipf's law is based on a study of the relationship of the frequency of occurrence of words in a tent and their ranking in a descending order. According to his, people often prefer to use familiar He stated, if words in the text are arranged in a descending order or frequency and then multiplied the numerical value of each rank (r) with its frequency and arrived at a product (c), which was constant for all the works.

Table 1: Research Output in the form of Papers:

\begin{tabular}{|c|c|c|c|c|c|}
\hline Sr. No. & Year & Vol. No. & No. of Issues & No. of Paper Published & Percentage \% \\
\hline 1 & 2012 & 110 & 4 & 45 & $19.74 \%$ \\
\hline 2 & 2013 & 111 & 4 & 46 & $20.18 \%$ \\
\hline 3 & 2014 & 112 & 4 & 30 & $13.16 \%$ \\
\hline 4 & 2015 & 113 & 1 & 08 & $3.07 \%$ \\
\hline 5 & 2016 & 114 & 3 & 17 & $7.46 \%$ \\
\hline 6 & 2017 & 115 & 4 & 29 & $12.72 \%$ \\
\hline
\end{tabular}




\begin{tabular}{|l|l|c|c|c|c|}
\hline 7 & 2018 & 116 & 4 & 42 & $18.43 \%$ \\
\hline 8 & 2019 & 117 & 1 & 12 & $5.26 \%$ \\
\hline \multicolumn{2}{|l|}{} & 8 & 25 & 229 & $100 \%$ \\
\hline
\end{tabular}

Table 1 shows the year wise paper published in The Indian Journals of Economics during 2012-2019 in all 25 issues from 8 volumes. 228 papers were published from which the highest number of papers are $46(20.18 \%)$ in volume 111 while the lowest number of paper are 7(3.07\%) in volume number 113.

Table 2: Authorship pattern

\begin{tabular}{|l|c|c|}
\hline No. of Authors & No. of contribution & Percentage \% \\
\hline One & 229 & $57.69 \%$ \\
\hline Two & 136 & $34.25 \%$ \\
\hline Three & 27 & $6.80 \%$ \\
\hline More than Three & 5 & $1.25 \%$ \\
\hline Total & 397 & $100 \%$ \\
\hline
\end{tabular}

Table 2 mirror the authorship pattern of contribution. It is seen that maximum number of contributions are from one author i.e. $229(57.69 \%)$ followed by two author with 136 (34.25\%), three authors have contributed 27 (6.80\%) papers and more than three authors contributed $5(1.25 \%)$ contribution.

Table 3: Year wise authorship pattern

\begin{tabular}{|c|c|c|c|c|c|c|c|}
\hline \multirow[t]{2}{*}{ Year } & \multirow{2}{*}{$\begin{array}{l}\text { Vol. } \\
\text { No. }\end{array}$} & \multirow{2}{*}{$\begin{array}{l}\text { No. of } \\
\text { Issues }\end{array}$} & \multicolumn{5}{|c|}{ Authorship Pattern } \\
\hline & & & One & Two & Three & More than three & Total \\
\hline 2012 & 110 & 4 & $45(19.74 \%)$ & $29(21.32 \%)$ & $9(33.33 \%)$ & $3(60 \%)$ & $86(21.66 \%)$ \\
\hline 2013 & 111 & 4 & $45(19.74 \%)$ & $26(21.12 \%)$ & $7(25.93 \%)$ & $1(20 \%)$ & $79(19.89 \%)$ \\
\hline 2014 & 112 & 4 & $33(14.41 \%)$ & $21(15.44 \%)$ & $1(3.70 \%)$ & $0(0 \%)$ & $55(13.81 \%)$ \\
\hline 2015 & 113 & 1 & $08(3.49 \%)$ & $5(3.68 \%)$ & $0(0 \%)$ & $0(0 \%)$ & $13(3.27 \%)$ \\
\hline 2016 & 114 & 3 & $17(7.42 \%)$ & $11(8.08 \%)$ & $1(3.70 \%)$ & $0(0 \%)$ & $29(7.30 \%)$ \\
\hline 2017 & 115 & 4 & $28(12.28 \%)$ & $17(12.5 \%)$ & $2(7.40 \%)$ & $1(20 \%)$ & $48(12.9 \%)$ \\
\hline 2018 & 116 & 4 & $42(18.34 \%)$ & $20(14.71 \%)$ & $5(18.52 \%)$ & $0(0 \%)$ & $67(16.87 \%)$ \\
\hline 2019 & 117 & 1 & $11(4.80 \%)$ & $7(5.14 \%)$ & $2(7.40 \%)$ & $0(0 \%)$ & $20(5.03 \%)$ \\
\hline \multicolumn{3}{|c|}{ Total } & $229(57.67 \%)$ & $136(34.25 \%)$ & $27(6.80 \%)$ & $5(1.25 \%)$ & $397(100 \%)$ \\
\hline
\end{tabular}

Table No.3 highlights year wise authorship pattern of contribution. Out of contribution made by one author most of the contribution made appear in the year 2012 i.e. 45 (19.74\%) while lowest contribution have been observed in 2019 i.e. it is 11(4.80\%). During 2014 to 2019 there seems to be consistency in the contribution of one author however, two author have dominated in their contribution as maximum $28(18.79 \%)$ articles have been contributed by them. Two authors have contributed significant during all years considered for the present study.

Table 4: Distribution of Citations

\begin{tabular}{|l|l|c|c|c|c|c|c|c|c|c|c|}
\hline S. No & Year & Vol. no. & $\begin{array}{l}\text { No. of. } \\
\text { Articles }\end{array}$ & \multicolumn{3}{|c|}{$\begin{array}{l}\text { Issue Wise No. of. } \\
\text { Citations }\end{array}$} & Total & Cumulative & \% & $\begin{array}{c}\text { Cumulative } \\
\%\end{array}$ \\
\hline 1 & 2012 & 110 & 45 & 52 & 60 & 85 & 65 & 262 & 262 & $8.61 \%$ & $8.61 \%$ \\
\hline 2 & 2013 & 111 & 46 & 40 & 75 & 65 & 55 & 235 & 497 & $7.72 \%$ & $16.33 \%$ \\
\hline 3 & 2014 & 112 & 30 & 80 & 115 & 90 & 102 & 387 & 884 & $12.72 \%$ & $29.05 \%$ \\
\hline 4 & 2015 & 113 & 07 & 125 & 98 & 70 & 117 & 410 & 1294 & $13.47 \%$ & $42.52 \%$ \\
\hline 5 & 2016 & 114 & 17 & 80 & 144 & 189 & 216 & 629 & 1923 & $20.67 \%$ & $63.19 \%$ \\
\hline 6 & 2017 & 115 & 27 & 91 & 139 & 108 & 127 & 465 & 2388 & $15.28 \%$ & $78.47 \%$ \\
\hline 7 & 2018 & 116 & 42 & 171 & 168 & 220 & 95 & 654 & 3042 & $21.49 \%$ & $99.96 \%$ \\
\hline 8 & 2019 & 117 & 12 & 150 & 140 & 110 & 87 & 487 & 3529 & $13.79 \%$ & $35.79 \%$ \\
\hline
\end{tabular}

Table 4 indicates that 229 citing articles have received 3529 citations. Most of the 654 are seen in the year 2016. Followed by 629 in the year 2014. The least number of citations 235 are observed in the year 2011 . The cited documents showed how they are related to the citing articles in theory and practice. 
Table 5: Top Eleven subject Facet

\begin{tabular}{|c|l|c|}
\hline S. No. & The Name of Subject Facet & No. of Papers \\
\hline 1 & Commerce & 67 \\
\hline 2 & Management & 63 \\
\hline 3 & E-Commerce & 15 \\
\hline 4 & Information Retrieval & 11 \\
\hline 5 & Technological Study & 9 \\
\hline 6 & Research Output & 7 \\
\hline 7 & Social Media & 5 \\
\hline 8 & E-Resources Usage & 5 \\
\hline 9 & Internet Use & 3 \\
\hline 10 & Professional Development & 2 \\
\hline 11 & Usage Study & \multicolumn{2}{|c|}{} \\
\hline
\end{tabular}

Table 5 shows that The Indian Journals of Economics tries to cover number of subjects in library and information science profession. However table number 9 points out on the prominent subject facets in which commerce stands at the top with 67 papers, followed by management with 63 papers, e-commerce with 15 papers. Information retrieval with 11 papers technological study with 9 papers. Research output with 7 papers, social media with 7 papers.

Table 6: Prominent Author

\begin{tabular}{|c|l|c|c|}
\hline S. No. & Author & No. of Articles & Rank \\
\hline 1 & Singh & 14 & 1 \\
\hline 2 & Datta & 10 & 2 \\
\hline 3 & Sharma & 7 & 3 \\
\hline 4 & Ahmad & 5 & 4 \\
\hline 5 & Mishra & 4 & 5 \\
\hline 6 & Kumar & 3 & 6 \\
\hline 7 & Gupta & 3 & 7 \\
\hline 8 & Ghosh & 2 & 8 \\
\hline
\end{tabular}

Most contributing authors can be viewed by Table 6 Singh is the most contributing author with 14 papers. He is followed by Datta has 10 papers, Sharma has 7 papers, Ahmad has 16 papers whereas Dipak Bansal has 15 papers and Arun Jaitley and Namita Sahay have 4 papers each on their credit. While getting the results for outstanding authors, all the authors have been given equal prominence irrespective of their first, second or any other position.

Table 7: Geographical Distribution

\begin{tabular}{|c|l|c|c|}
\hline S. No. & \multicolumn{1}{|c|}{ State } & No. of Papers & Rank \\
\hline 1 & New Delhi & 27 & 1 \\
\hline 2 & Andra Pradesh & 14 & 2 \\
\hline 3 & Tamil Nadu & 11 & 3 \\
\hline 4 & Maharastra & 9 & 4 \\
\hline 5 & Assam & 9 & 4 \\
\hline 6 & Kerala & 6 & 5 \\
\hline 7 & HimachalPradesh & 4 & 6 \\
\hline 8 & Rajasthan & 4 & 6 \\
\hline 9 & Karnatak & 4 & 6 \\
\hline 10 & Punjab & 3 & 7 \\
\hline 11 & Chennai & 1 & 8 \\
\hline 12 & Orissa & 1 & 8 \\
\hline 13 & Uttar Pradesh & 1 & 8 \\
\hline 14 & Bangal & 1 & \\
\hline
\end{tabular}

Table 7 reflects the geographical distribution of papers from the various sate of India New Delhi has got the first position as 27 papers have coming from it, Andra Pradesh is second in the ranking giving output of 14 papers. The other states are followed by Tamilnadu, Maharashtra, Assam, kerala, Himchal Pradesh, Rajasthan, Karnataka, and Punjab Etc. 
Table 8: Length of Articles

\begin{tabular}{|c|c|c|c|}
\hline S. No. & No. of Articles & Pages & Percentage \% \\
\hline 1 & 1 & 64 & $0.19 \%$ \\
\hline 2 & 1 & 48 & $0.19 \%$ \\
\hline 3 & 1 & 40 & $0.19 \%$ \\
\hline 4 & 7 & 34 & $1.30 \%$ \\
\hline 5 & 18 & 32 & $3.36 \%$ \\
\hline 6 & 30 & 30 & $5.59 \%$ \\
\hline 7 & 8 & 28 & $1.49 \%$ \\
\hline 8 & 7 & 26 & $1.30 \%$ \\
\hline 9 & 9 & 24 & $1.68 \%$ \\
\hline 10 & 38 & 22 & $7.08 \%$ \\
\hline 11 & 40 & 20 & $7.44 \%$ \\
\hline 12 & 36 & 18 & $6.70 \%$ \\
\hline 13 & 1 & 17 & $0.19 \%$ \\
\hline 14 & 27 & 16 & $5.02 \%$ \\
\hline 15 & 26 & 14 & $4.84 \%$ \\
\hline 16 & 25 & 12 & $4.66 \%$ \\
\hline 17 & 49 & 10 & $9.12 \%$ \\
\hline 18 & 43 & 8 & $8.00 \%$ \\
\hline 19 & 17 & 7 & $3.17 \%$ \\
\hline 20 & 33 & 6 & $6.14 \%$ \\
\hline 21 & 26 & 5 & $4.84 \%$ \\
\hline 22 & 23 & 4 & $4.29 \%$ \\
\hline 23 & 20 & 3 & $3.72 \%$ \\
\hline 24 & 38 & 2 & $7.08 \%$ \\
\hline 25 & 13 & 1 & $2.42 \%$ \\
\hline Total & 229 & & $100 \%$ \\
\hline & & & \\
\hline
\end{tabular}

Table 8 indicates the length of papers published in Bibliometric study of The Indian Journals of Economics during the period under study out of 229 papers, 49 articles having 10 pages, 43 articles having 20 pages. Forty eight and 40 pages remaining details can be viewed through this table.

\section{Result and Discussion}

The popularity in the adoption of bibliometric techniques in various concerned lines stimulated stupendous growth of literature on bibliometrics and its own area. A bibliometric study of "The Indian Journals of Economics" has published 537 Articles during 2012-2019 within 28 issues. The citing details of all the articles are considered for the study. The considered detail is collected using MS-Excel sheet. The field such author institutions from which they are belong geographical distribution of author, length of articles. Data is gathered was analyzed which revealed the during result.

537 research papers were published during the period consider for the study maximum 88 articles are published in the year 2011 However there is no significant difference in quantitative research output of the published articles.

As far as authorship pattern is concerned single author have dominated as most of the contribution that is 537 are on their credit, two is 149 , three is 32 and more than three is only 7. Authorship pattern indicated that collaborative authorship is gaining ground among the library professional. Never the less two authors are followed by the three authors in terms of contributions. There is a lot of scope of collaborative research in the field of social science when we considered research in science and technology.
When we compare authorship pattern for each individual year, maximum contributions from one author appears in the year 2013 as $45(19.74 \%)$ articles appear in this year. From 2012-2019 there seems to be great consistency by research output of two authors. Interestingly two authors have maximum contribution in the year 2013 as $29(21.32 \%)$. The contribution by three authors and more than three authors though have less contribution, they are visible with $27(6.80 \%)$ and $5(1.25 \%)$. When compare three authors and more than three with the contribution by one author and two authors they are overshadowed by the formers.

Bibliometrics with popular subject facet found in study. It is also noteworthy. Bibliometric of The Indian Journals of Economics has published as special issue Eugene Garfield who is concern with bibliometric and its similar discipline.

Most of the citations 654 are seen in the year 2019 followed by 629 in the year 2017. The least number of citations 235 are observed in the year 2013.

Among the most prolific authors Singh is the first as she leaded the ranking list with 14 articles, she is followed by Datta and Sharma 10 and 7 articles respectively all these three authors have concern with study of bibliometric this has an connected with the dominant subject facet. 
Maximum research paper are published by the author from New Delhi this cities followed Andhra Pradesh, Tamil nadu, Maharashtra and Assam is the $5^{\text {th }}$ in list.

As the Bibliometric study of The Indian Journals of Economics is peered listed open access journal many of the foreign authors are regularly publishing their research through this journals, Nigeria, ShriLanka, Bangladesh Tanzania, Iran are leading countries considering the research output.

There are maximum 49 articles which are having 10 pages and there is only one article which has 64 pages, 48 pages and 40 pages. 216 articles have between 4 to 12 pages.

\section{Conclusion}

To conclude, let's have the overlook of the study undertaken by the Bibliometric study of The Indian Journals of Economics 2012-2019 has been selected as the study keeping as mind, the time is essence for the completion of his work, the scope has been limited the issues of Bibliometric of The Indian Journals of Economics published between 2012-2019.

Bibliometrics of The Indian Journals of Economics has been selected for the purpose of the bibliometrics studies owing to its popularity and contribution considering Indian background bibliometric of The Indian Journals of Economics are served as an intellectual impetus to the library professional working in India. It has been satisfying the intellectual need to the researcher of the student across the world. The citation appended to the references of each article has been gathered by using MS-Excel sheet. For this the fields like author, title, name of the journal etc. are created. The collected data is analyzed to derive the reasons although the results are not very comprehensive, yet they are able to show some light on the bibliometric study pattern of library professions. The researcher admits that there are limitations for the generalization of results. However, it is excellent piece of work the results of which need to be strengthened by more bibliometrics studies.

\section{Conflict of Interest}

None.

\section{Source of Funding}

None.

\section{References}

1. Afolaba M.A. Citation Study of Literature of Bibliographical Classification Cited Library Science with a Slant to Doc. and. Inf Stud 1983;20(4):228-34.

2. Agrawal S.P. Indian Social Science Periodical: Current Status. Libr Herald 1983;1:30-45.

3. Lal A. Ranking of Periodicals in the Field Soil Science. Ann Libr Sci 37(2): 67-73, 1990.

4. Begum Khaiser Jhan And Lalitha, Trends In Indian Agricultural Research: Anlyatical Study. Ann Libr Sci 1986;33(4):163-72.

5. Barooch PK. Pattern of: Information Use by Indian Entomogist. Ann Libr Sci 1993;40(3):104-13.
6. Bhat VG, Raju E. Ranking of Periodicals in the Field Astronautics and Aeronautics. Ann. Libr Sci 1977;24(3-4):114.

7. Chakarborty A.R, Chakraboty B. Gaints in Library and Information Science. Ann Libr Sci 1978;25(1-4):52-54.

8. Ghosh J.S. Literature Searching With Sci: An Experimental Study. Ann Libr Sci 1967;14(3):138-42.

9. Gupta B.M. A Citation Analysis of Internal and External Connection of a Research Branch; A Case Study of Solar Energy Research in the Ussr. Ann Lib Sci 1980;27(1-4):61-5.

10. Gupta B.M. Networks Of Scientific Papers: A Comparative Analysis of Co-Citation, Bibliographic Coupling and Direct Citation. Ann Libr Sci 1977;24(3-4):137-43.

11. Gupta D.K. A Clitography on Lepichon's Article on Seaflower Spreading and Continental. Iaslic Bull 1983;28(2);49-58.

12. Gopinath M.A. Bibliography Citation in Biochemistry: A Chronological. Anal Libr Sci Slant 1985;22(3):175-91.

13. Gupta D.K. Application Analysis Study of Sub Discipline of Exploration Geophysics. Inicae 1985;4(1):5-13.

14. Gupta D.K. Application of Bradfords Low to Citation Data of Ethiopian Medical Journal. Ann Libr Sci 1993.

15. Hadagail P.B. Frequently Cited Periodicals by Indian Agricyltural Economist: A Citation Analysis. Iaslic Bull 1983;28(2):59-66.

16. Singh H. Application of Biotechnology In Mass Health CareLiterature Trend. Ann Libr Sci 1992;39(1):19-25.

17. Gopainath M.A. Across The Frontiers; Impact of Foreign Journal in Library Science in India: A Citation Analysis. Libr Sci Slant Documentation Inf Stud 1993.

18. S. Humayoon, Kabir Citation in World of Bibliometrics Research: An Analysis. Lib Sci Slant Inf Stud 1993.

19. Kumar K, User's Survey Concerning Teachers and Researcher Scholars in Dept. of Chemistry. University of Delhi. Ann Lib Sci 1960;5(4)175-207.

20. Kapoor S.K. Citation Analysis of Earth Science Literature. Ann Libr Sci 1984;31(12):56-62.

21. Kale S.K. Citation Analysis of Ph.D. Thesis Social Science And Literature Submitted to Amravati University During 1988-93 (A Dissertation) Submitted To Amravati University. 1994.

22. Kunda A.K. Citation of The Source Journal In The Filed of Lib. Science And Their Ranking. Ann Libr Sci 1980;27(14):130-4.

23. Khanna J.K. Advanced In Librarian Ship. New Delhi. $1985 ; 58$

24. Kumar R.P. Periodicals in L \&I.S. India In. Library and Information Science Ed. By P.K. Gupta and Usha Pawan, Jaipur, 1986;245-55.

25. Musib S.K. Periodicals in L\& I.S.: Nature And Growth Patterns. Iaslic Bull 1986;31(1):35-86.

26. Maheshwar Appa B.S, Prakash B.P. Literature Use Pattern by The Researcher Iin The Field of Botany: A Citation Study of Doctoral Thesis. Jl. Libr Sci Inf Sci 1982;7(1):15-22.

27. Mohan Roy R.P. Citation Analysis: A New Tool For Modern Libraries. Iaslic Bull 1980;25(3):109-16.

28. Mete M.V. Citation Analysis of "Annals of Library Science and Documentation' During 1984-93 (Dissertation Submitted To Amravati University, 1995.

29. Musib S.K. Age of Literature Studies in Agriculture Economics. Ann Libr Sci 1986;33(1-2):27-30.

30. Mahopatra, Gayatri Highly Author's Journal and Books in Indian Library and Information Science Literature. $\mathrm{Lib} \mathrm{Sci}$ Slant Inf Stud 1993.

31. Verma M. Cited Analysis of Some Selected Indian Journal in Economics Ann Libr Sci 1994;41(1):33-9.

32. Mohanta, R.B. Information Use Pattern Rabindranath of Indian Library and Information Scientist: A Citation Study. Herald Libr Sci 1992;31(34):217-24. 
33. Sen B.K, Kumar N. Indian Contribution in Bibliometrics 1958-1984: A Revies. Ann Libr Sci 1986;33(3):85-90.

34. Sengupta I.N. Bibliometrics and Identification of Core Periodicals. Herald Libr Sci 1990;226-34.

35. Sharma, S.C. Citation Patterns and Analysis. Ila Bull. 1981;17(34):234-40.

36. Vaishanav A.A. Citation Analysis of Herald of Library Science. Herald Libr Sci 1990;24(3-4):252-9.
37. Weinstocks M. Citation Indexes. An Encyclopedia Library and Information Science New York, 1971;5:166-40.

How to cite: Chore NV. Bibliometric study of the Indian journal of economics. IP Indian J Libr Sci Inf Techno 2020;5(2):54-60. 